\title{
LOCAL JOB FLOWS IN NEW ZEALAND ${ }^{1}$
}

\author{
David C Maré \\ Jason Timmins \\ Motu Economic and Public Policy Research Trust
}

\begin{abstract}
Small changes in the level of employment are generally the result of a large number of jobs being created and a roughly balancing number of jobs being destroyed. In this paper we examine patterns of job creation and destruction for local labour markets in New Zealand between 1987 and 2003. The growth or decline of employment in local labour markets is far from homogeneous. The paper focuses on whether local labour markets experience greater employment growth following periods of high rates of simultaneous job creation and destruction (job churn). However, we find little evidence to support this hypothesis. The estimated effect of the level of job churn on future employment growth, within labour markets, was found to be statistically and economically insignificant.
\end{abstract}

\section{Introduction}

Is the churning of jobs important for employment growth within local labour market areas (LMAs)? Do LMAs experience greater employment growth following periods of high rates of job reallocation? Why might job turnover be important for future employment growth? The motivation for these questions comes from the analysis of the process of creative destruction. Economic growth, within a market involves considerable reallocation of production inputs. Competition between firms encourages the introduction of new and better products and new and better ways of making the products. The effect of such technological change was termed 'creative destruction' by Schumpeter (1942), who described how the introduction of new products and new technology required the destruction of outdated ideas and methods. The consequence of this creation and destruction is that production resources (e.g. labour) are shifted, as old products and processes are destroyed, to the production of new products and processes.

Job flows data supports the existence of large-scale job reallocation. Davis and Haltiwanger (1999) find that the constant churning of job opportunities, through the creation and destruction of jobs, is a common feature of firm dynamics in both developed and developing countries. Most job creation and destruction occurs simultaneously. For example, in New Zealand, between 1994 and 2001, around $30 \%$ of jobs were created and destroyed annually, whereas net employment change was only $2 \%$ (Carroll et al (2002)). Another important feature of job flows is that the majority of job reallocation does not represent a shift in labour resources from one sector to another due to changes in demand. Davis and Haltiwanger (1991) grouped firms by industry sector and geographic region and found that job flows between industry sectors and regions were very small when compared with the churning of job opportunities that occurred within each industry and region.
Jobs can be reallocated from firms that contract their employment or cease production (die) to firms that either enter production (births) or expand employment. Caballero and Hammour (1994) and Cooper et al (1999) characterise creative destruction as the adoption of new technology by firms. Caballero and Hammour (1994) assume that new technology is adopted by new firms and old technology is destroyed by firms exiting production (job reallocation through firm births and deaths). Caballero and Hammour examined how changes in demand were accommodated by the job creation and job destruction rates. For example, when demand is low does the creation of new firms slow down or stop and destruction continue unchanged? Using manufacturing data from the US between 1972:2 and 1986:4, they found that job creation was smoothed across the business cycle (change in demand), whereas job destruction varied counter-cyclically to the business cycle. They concluded that recessions are periods of shakeouts as firms undergo reorganisation due to the relatively low opportunity cost of unemployment. The pool of unemployed is then slowly reduced because growth periods are considerably longer than periods of decline (recessions).

Cooper et al (1999) examined the adoption of new technology within firms, referred to as retooling (job reallocation through existing firms expanding and contracting). Retooling can lead to within and between plant job reallocation, changing both the level and skill mix of the plant's workforce.

As noted by Caballero and Hammour (1994) the process of creative destruction often involves distressing job losses, and can result in a political response to protect those jobs. If job reallocation is an important component in the improvement of living standards, policies that protect existing jobs may hinder the pace of renovation and lead to technological 'sclerosis'. However, large job losses during recessions suggest that job creation and destruction is not always efficient in the reallocation of labour within an economy. 


\section{Methods}

The study uses empirical measures of job flows that are commonly used in the literature on job creation and destruction. ${ }^{2}$ Let $E_{i t}$ be the level of employment of firm-i in year-t, then the relative employment change from year- $(t-1)$ to year-t is defined as

$$
\Delta e_{i t}=\frac{\left(E_{i t}-E_{i t-1}\right)}{\left(E_{i t}+E_{i t-1}\right) / 2} \quad \in[-2,2]
$$

Note that if firm- $i$ does not exist in year-t then $E_{i 1}=0$. This definition of relative employment change has two advantages over conventional growth rate definitions: it treats employment growth and contraction symmetrically, and handles firm births and deaths. In addition $\Delta \mathrm{e}_{\mathrm{it}}$ is monotonically related to the conventional growth rate definition, and is bounded by $+/-2{ }^{3}$

The aggregate job creation rate ( $\left.\Delta e_{t}^{c}\right)$ measures the total increase in employment across expanding and new firms relative to average total employment in all firms. Similarly, the aggregate job destruction rate $\left(\Delta e_{t}^{d}\right)$ measures the total decrease in employment across contracting and dying firms relative to average total employment. The aggregate net employment growth rate $\left(\Delta e_{t}^{m e t}\right)$ is then simply the difference between the aggregate job creation and destruction rates. Finally, the cxcess job reallocation rate ( $\Delta e_{i}^{\text {IS }}$ ), which measures the excess job flows over and above that required to achieve the net employment growth, is the sum of the job creation and destruction rates, or the gross job rea!location rate $\left(\Delta e_{i}^{\text {gross }}\right)$, less the net employment rate. Specifically,

$$
\begin{aligned}
& \Delta e_{i}^{c}=\sum_{i}\left(1\left(E_{i t-1}<E_{i t}\right) \cdot\left(E_{i t}-E_{i t-1}\right)\right) / \overline{E_{t}} \\
& \Delta e_{t}^{d}=\sum_{i}\left(1\left(E_{i t-1}>E_{i t}\right) \cdot\left(E_{i t-1}-E_{i t}\right)\right) / \bar{E}_{t} \\
& \Delta e_{1}^{n e t}=\Delta e_{1}^{c}-\Delta e_{t}^{d} .
\end{aligned}
$$

and

$$
\begin{aligned}
& \Delta e_{1}^{k r e s s}=\Delta e_{1}^{c}+\Delta e_{1}^{d} \\
& \Delta e_{1}^{\text {is }}=\Delta e_{1}^{g r o s s}-\left|\Delta e_{1}^{n e t}\right|
\end{aligned}
$$

where $\bar{E}_{t}=\sum_{i} \bar{E}_{i t}$ is the average total employment in years- $(t-1)$ and $I$, and $I($.$) is an indicator function which$ is equal to $I$ if the enclosed expression is true and equal to 0 otherwise.
Excess reallocation of jobs can be disaggregated into the proportion that occurs within and between different sectors-s (LMAs) and is given by:

$$
\begin{aligned}
\underbrace{\Delta e_{t}^{\text {gross }}-\left|\Delta e_{t}^{\text {net }}\right|}_{\text {Excess Reallocation }}= & \underbrace{\left(\sum_{s}\left|\Delta e_{s t}^{\text {net }}\right|-\left|\Delta e_{t}^{\text {net }}\right|\right)}_{\text {Between }} \\
& +\underbrace{\sum_{s}\left(\Delta e_{s t}^{\text {gross }}-\left|\Delta e_{s t}^{\text {net }}\right|\right)}_{\text {Within }}
\end{aligned}
$$

The first term sums the absolute net changes in employment for each LMA and compares the total to the overall net employment change across all LMAs. If all LMAs experience positive employment change, within an annual period, then the first term will equal zero. The second term sums excess job reallocation within LMAs.

\section{Data $^{4}$}

The data used in this study are taken from Statistics New Zealand's (SNZ) business demography datasets, and provide annual longitudinal data on the majority of New Zealand businesses from 1987 to 2003, measured as at February each year. Access to the data used in this study was provided by Statistics New Zealand under conditions designed to give effect to the security and confidentiality provisions of the Statistics Act 1975.

The target population for these datasets is 'all New Zealand businesses', although, as outlined below, there are some exclusions and variations over time in coverage. The business demography dataset is updated in February each year as an annual snap-shot from the SNZ Business Frame at that point in time. From 1987 to 1994, the data are taken from the SNZ Business Directory, and from 1994 to 2003 , they are from the SNZ Business Frame.

The data are collected from a combination of survey and administrative sources - primarily the SNZ Annual Business Frame Update Survey $\left(\mathrm{ABFU}^{5}\right)$ which has been conducted in mid-February each year, since 1987, and the Inland Revenue Department's (IRD) Client Registration File, which is the universe of GST registered enterprises.

Data are available for business units (called activity units until 1996, and geographic units thereafter), and for enterprises. A business unit relates to a particular business site and an enterprise may contain several business units. In this paper, we deal exclusively with business units and not enterprises.

The criteria for including activity units in the database is described in detail in Carroll et al (2002) and Statistics New Zealand (2004). A major change in the data is the shift from GST-registration to economic significance, which occurred in 1994. From 1987 to 1994, business units were included only if they belonged to a GSTregistered enterprise (i.e. with GST sales of at least $\$ 30,000)$. From 1994 the business unit was included 
only if it belonged to an 'economically significant' enterprise, where an enterprise was regarded as economically significant if it met any one of the following criteria: had greater than $\$ 30,000$ annual GST expenses or sales; had more than 2 full-time equivalent paid employees; was in a GST-exempt industry except residential property leasing and rental; or; was part of a group of enterprises.

To gauge the impact of the series discontinuity in 1994 on our analysis of changes over time, we examined the time pattern of employment and the number of business units - in total and disaggregated by industry, firm-size, and region. In aggregate, the change in definition caused a 10 percent decline in the number of business units covered, and a 1 percent decline in measured full-timeequivalent employment $\left(\mathrm{FTE}=\mathrm{FT}+0.5^{*} \mathrm{PT}\right.$, including working proprietors). As would be expected, the changes were more noticeable across the firm-size distribution, with the declines resulting from definitional change being confined to small ( $0-5$ FTE) firms. Given that most of our analyses are employment-weighted, the impact is likely to be small. Furthermore, it appears that the geographic and industry impact of the changes were widespread, so that the discontinuities in the sort of indices that we are looking at will be minor. While we remain cautious in interpreting any changes around 1994, we consider that pooled analysis is still justified.

The industry coverage of the business demography data has also changed over time. The primary exclusion from the BDS is firms in agricultural production industries. Until 1996 the industry selection criteria were based on the New Zealand Standard Industrial Classification (NZSIC); while from 1997 onwards the Australian and New Zealand SIC (ANZSIC) was used. The analysis in this paper is restricted to 4-digit industries that remained in coverage throughout the study period. Apart from the exclusion of agricultural industries that were surveyed in 1998 , this restriction is most severe in the most recent period, where excluded industries contained just over 4 percent of FTE employment. The locations of business units are recorded at the level of meshblocks, which range in size from city blocks to large areas of rural land. We look at the distribution of employment across larger areas, which are obtained by aggregating meshblocks. Our main analyses group employment into 58 labour market areas (LMAs), as defined by Newell and Papps (2001) on the basis of commuting patterns. ${ }^{8}$ It was necessary to merge 3 LMAs, with an adjacent LMA, to protect confidentiality. The LMAs were Tokoroa, Waipukurau and Mackenzie, which were merged with Otorohanga, Hastings and Waimate respectively.

All of the analyses that follow restrict attention to industries that were included in the Business Demography dataset continuously from 1987 to 2003 . There are 424 4-digit industries that are represented in the data in at least one period, 17 are dropped because they are out of coverage in some periods. Our measure of employment includes full and part-time employees and working proprietors.

\section{Results}

How much job churning occurs within New Zealand? Previous work by Carroll et al (2002) reported that on average approximately one in three jobs turned over annually between 1994 and $2001^{9}$. High job turnover rates are a feature found in other countries. Davis and Haltiwanger (1999) found, from a survey of 18 countries, ${ }^{10}$ that job reallocation varied between $10 \%$ and $35 \%$. Differences in data collection and measurement procedures make it difficult to compare job reallocation rates between countries. Mills and Timmins (2004) attempted to harmonize the collection and measurement of New Zealand firm dynamics data with several OECD countries and found that New Zealand's job turnover rate was among the highest within the OECD distribution.

\section{Figure 1: Annual Job Creation, Job Destruction, Gross Job Reallocation and Net Employment Change for the Years 1987 to 2002}

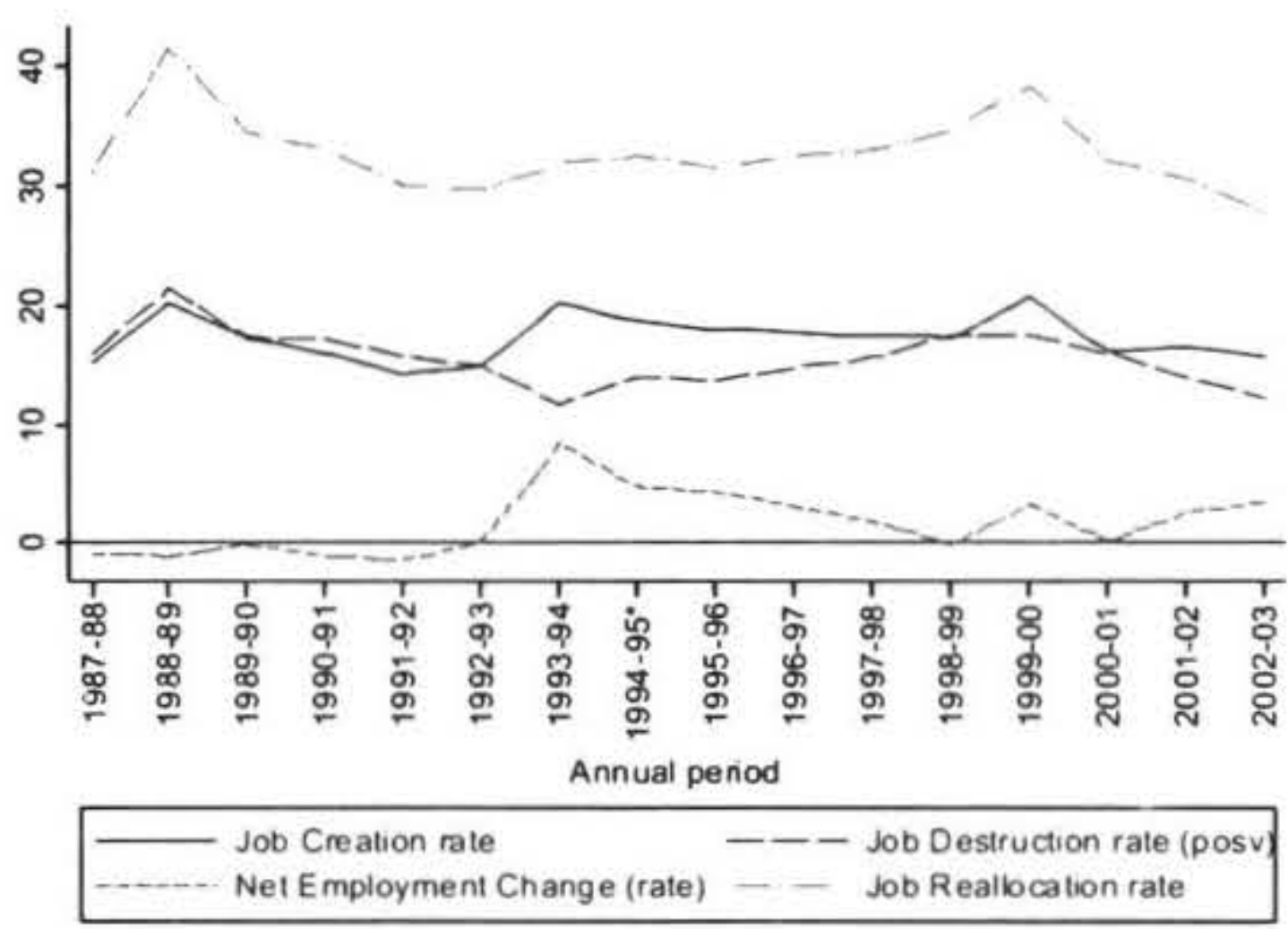

Notes: 1994-95 was the first period that introduced "economic significance" to determine the inclusion of firms within the BDS. Before 1994 firms were selected if their GST returns exceeded $\$ 30.000$.

Figure 1 displays job creation, job destruction, gross job reallocation and net job reallocation rates for the 16 annual periods $1987-98$ to $2002-03$.

On average $32.8 \%$ of jobs were either created $(17.3 \%)$ or destroyed $(15.5 \%)$ each year, while net employment change was only around $1.8 \%$. Excess (simultaneous) creation and destruction of jobs amount to $29.6 \%$ of employment. Gross job reallocation varied between $27.7 \%$ and $41.6 \%$, across the 16 annual periods. Relatively high rates of gross job reallocation are associated with periods of relatively low net employment change. The correlation between annual gross job reallocation and net employment change is negative, but small $(-0.183)$ and not significant at the $5 \%$ level.

Job creation rates range from $14.3 \%$ to $20.8 \%$, whereas, job destruction rates range from $11.8 \%$ to $21.3 \%$. Between 1987 and 1993 job creation and destruction moved together, but, after 1993, job creation and job destruction diverged and moved in opposite directions. 
The correlation coefficient between job creation and destruction is positive $(0.209)$, but is not significant at $5 \%$ level. In comparison, Davis and Haltiwanger (1992) report a negative relationship between job creation and destruction. The New Zealand patterns shown in Figure 1 also show little evidence that job destruction being more cyclically volatile - a finding reported by Davis and Haltiwanger (1992) for the US.

Comparisons with other studies of firm dynamics within New Zealand are complicated by the use of different measures of job creation and destruction and the coverage of different industries. The OECD (1996) examined private sector firm dynamics within New Zealand between 1987 and $1993^{11}$ and reported a gross job reallocation rate of $35.5 \%$, which compares favourably with the gross job reallocation rate towards the beginning of the study period in Figure 1. Carroll et al (2002) analysed New Zealand firm dynamics between 1994 and 2001 and found that roughly a third of jobs turnover annually, which is not that dissimilar to job reallocation rates reported in Figure 1. ${ }^{12}$

Figure I suggests that job turnover is relatively large within New Zealand as a whole, but does this picture hold within LMAs? It is possible that the high national rates of job turnover are being driven by strong growth within a few large LMAs (e.g. Auckland) and that jobs are being reallocated between rather than within LMAs. Figure 2 presents a histogram of LMA excess job reallocation rates pooled over the 16 annual periods within the study dataset.

Figure 2: Histogram of Pooled LMA Excess Job Reallocation Rates

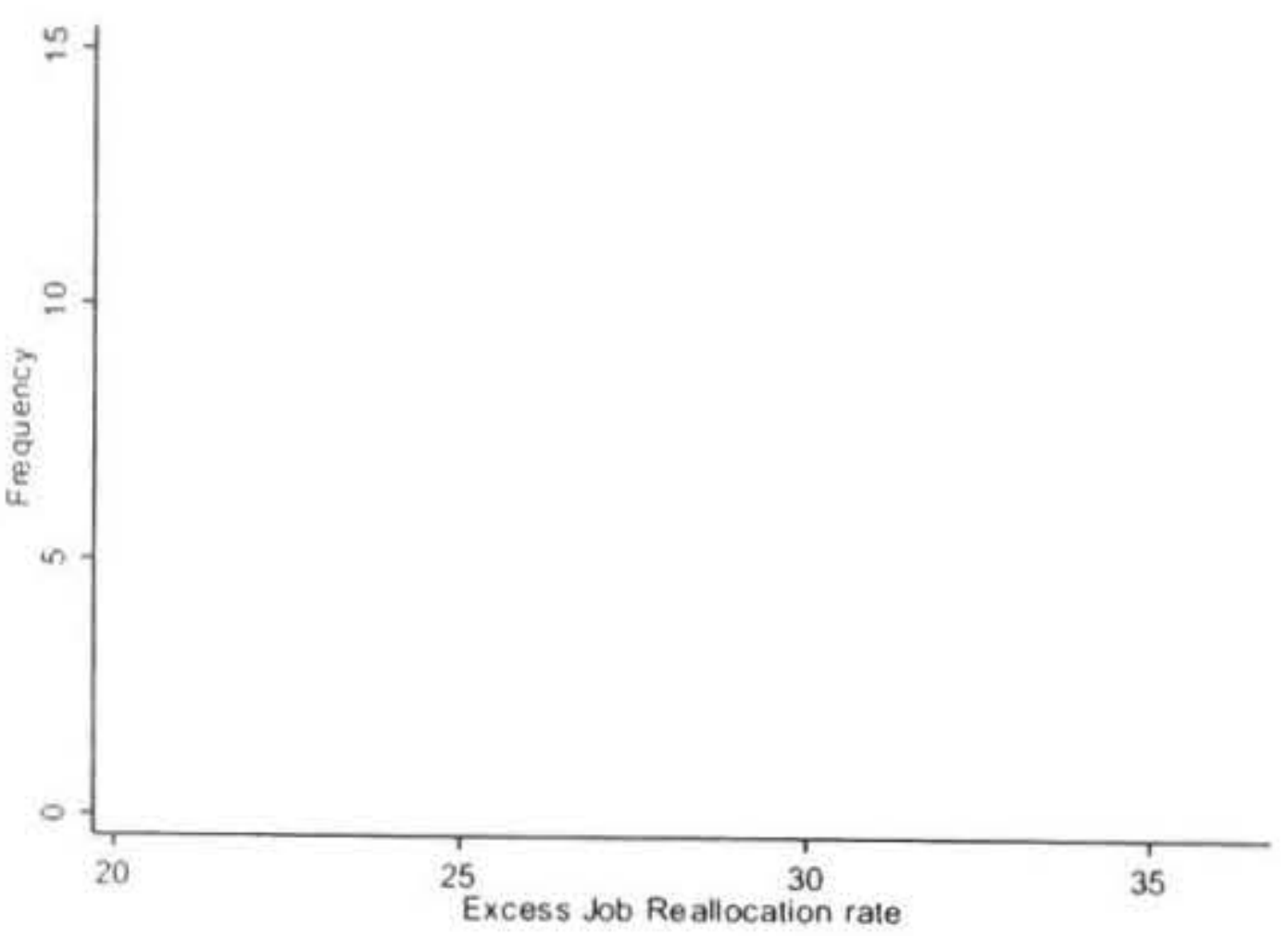

Note: 55 LMA pooled across 16 anmual periods

The horizontal axis in Figure 2 displays excess job reallocation rates and the vertical axis records the frequency of LMAs. Excess job reallocation ranges from $23.4 \%$ to $35.8 \%$. The mean LMA excess job reallocation rate is $29.4 \%$, compared with the national rate of $29.6 \%$, and the standard deviation is $2.4 \%$. There are a couple of outliers, but the majority of LMAs have an excess job reallocation rates between $25 \%$ and $35 \%$. The rates are similar in magnitude to the rates for the aggregate labour market, suggesting that within-LMA churning is an important part of the observed turnover rates.

The national excess job reallocation rate represents within LMA job reallocation, shown in Figure 2, and between LMA job reallocation due to LMA net employment changes. Table 1 decomposes excess job reallocation into the part that is accounted for by simultaneous creation and destruction within LMAs and the part that is accounted for by the reallocation of jobs between LMAs as a result of LMAs growing at different rates.

Table 1: Between LMA Employment Shifts and Within LMA Excess Job Reallocation

\begin{tabular}{|c|c|c|c|c|}
\hline Period & \multicolumn{2}{|c|}{ Between } & \multicolumn{2}{|c|}{ Within } \\
\hline $1987-88$ & 27038 & $(7.2 \%)$ & 350203 & $(92.8 \%)$ \\
\hline $1988-89$ & 24410 & $(4.8 \%)$ & 482687 & $(95.2 \%)$ \\
\hline $1989-90$ & 19922 & $(4.7 \%)$ & 402383 & $(95.3 \%)$ \\
\hline $1990-91$ & 13558 & $(3.5 \%)$ & 376725 & $(96.5 \%)$ \\
\hline $1991-92$ & 5360 & $(1.6 \%)$ & 338896 & $(98.4 \%)$ \\
\hline $1992-93$ & 14418 & $(4.1 \%)$ & 340221 & $(95.9 \%)$ \\
\hline $1993-94$ & 90 & $(0.0 \%)$ & 296404 & $(100.0 \%)$ \\
\hline $1994-95^{*}$ & 3810 & $(1.0 \%)$ & 360507 & $(99.0 \%)$ \\
\hline $1995-96$ & 642 & $(0.2 \%)$ & 372192 & $(99.8 \%)$ \\
\hline $1996-97$ & 3954 & $(0.9 \%)$ & 413738 & $(99.1 \%)$ \\
\hline $1997-98$ & 11328 & $(2.5 \%)$ & 444586 & $(97.5 \%)$ \\
\hline $1998-99$ & 22362 & $(4.4 \%)$ & 489796 & $(95.6 \%)$ \\
\hline 1999-00 & 6114 & $(1.2 \%)$ & 521781 & $(98.8 \%)$ \\
\hline $2000-01$ & 23958 & $(4.9 \%)$ & 461068 & $(95.1 \%)$ \\
\hline $2001-02$ & 2928 & $(0.7 \%)$ & 433799 & $(99.3 \%)$ \\
\hline $2002-03$ & 1026 & $(0.3 \%)$ & 389904 & $(99.7 \%)$ \\
\hline Pooled & 180918 & $(2.7 \%)$ & 6474890 & $(97.3 \%)$ \\
\hline
\end{tabular}

Excludes between LMA jobs reallocation due to firms migrating

For each annual period Table 1 reports the number and percentage of job reallocated within and between LMAs. On average between 1987-88 and 2002-03 the majority of excess job flows occurred within LMAs. ${ }^{13}$ On average only $2.7 \%$ of excess job reallocation was due to job flows between LMAs. Between-LMA job reallocation accounts for $0.7 \%$ to $7.2 \%$ of total excess reallocation, whereas within-LMA job reallocation rate accounts for $92.8 \%$ to $100.0 \%$. 
Figure 2 suggests that LMAs have high excess job reallocation rates, similar to the national rate and Table 1 shows that most of the excess job reallocation is due to job turnover within LMAs. This supports the findings of Davis and Haltiwanger (1991) that most job reallocation occurred within regions and not between them. Having established that excessive job chum is a feature within all LMAs within New Zealand and the principle method for reallocating jobs, we return to the question of whether excessive job churn is related to future employment growth within LMAs.

We use an Ordinary Least Squares (OLS) regression model to estimate the effect of job reallocation on future employment growth. The model is given by:

$$
\begin{aligned}
\text { net }_{i t}= & \beta_{0}+\beta_{1} \text { excess }_{i(t-n)}+\beta_{2} \text { net }_{i(t-n)} \\
& +\beta_{3} \text { jebirths }_{i(t-n)}+\beta_{4} \text { jddeaths }_{i(t-n)} \\
& +a_{i}+\phi_{t}+\varepsilon_{i t}
\end{aligned}
$$

Where the dependent variable net is net employment change within LMA-i at annual period-t. The independent variables excess, net, jcbirths and jddeaths represent lagged excess job reallocation, employment growth, the proportion of job creation due to firm births and the proportion of job destruction due to firm deaths for $n$ annual periods prior to annual period $t$. The variable $a_{i}$ captures unobserved time-constant factors and $\phi_{1}$ captures unobserved time-varying factors that affect the dependent variable net. $\varepsilon$ is an error term and represents the unexplained variation in the dependent variable net.

Excess job reallocation is the variable of interest and measures the additional creation and destruction of jobs, that occurs in excess of that required to achieve the net change in employment, $n$ annual periods before an employment change. We test for two omitted variables, lagged employment growth and the composition of job reallocation. Figure 1 suggested that excess job reallocation and net employment change are negatively correlated over the period of study. We include employment growth to test whether the estimated effect of lagged excess job reallocation on net employment change is biased by omitting lagged measures of employment growth. We also test whether the effect on the lagged excess job reallocation point estimate is biased if measures of the composition of job reallocation are excluded. It is not possible to include lagged measures of job creation and destruction within the model specified above as this would result in perfect collinarity between the independent variables. ${ }^{14}$ Instead the composition variables have been specified as the proportion of job creation and destruction that is within new firms and firms that die. A positive coefficient on the jcbriths variable suggests that a high proportion of job creation in new firms is correlated with future employment growth, whereas a negative relationship suggests that a high proportion of job creation within existing firms is correlated with future net employment change.

To control for the effects of unobserved differences in net employment change between annual periods and LMAs the regression model is specified with period and LMA fixed effects. Period fixed effects control for unobserved time-varying differences in net employment change that are constant across LMAs (e.g. the business cycle). LMA fixed effects control for unobserved differences in LMA employment growth rates that are time invariant. Differences in LMA employment growth rates could be explained by different industry shares across LMAs. For example, rural LMAs would have a higher share of firms engaged in agriculture, compared with urban areas where the share of manufacturing firms is likely to be higher. Table 2 presents different specifications of the regression model outlined in equation (1).

The first column tests the effect of a one and two-year lagged excess job reallocation rate on net employment change. The model specification in column one is repeated with the addition of period fixed effects (column 2) and with both period and LMA fixed effects (column 3). When period and LMA fixed effects are excluded the coefficient on the one-year lagged excess job reallocation rate is negative $(-0.057)$ and significant at the $10 \%$ level. The effect of a two-year lagged excess job reallocation rate is negative $(-0.009)$, but is practically and statistically insignificant. The results from column one suggest that a $10 \%$ increase in excess job reallocation will result in a half a percent decrease in employment growth next period. However, the effect of excess job reallocation, on net employment growth, does not appear to extend back two annual periods.

The negative relationship between job churn and future employment growth reported in column one, could be due to macro business cycle effects. Figure 1 shows that periods of relatively low employment growth are associated with relatively high periods of excess job reallocation (the difference between the gross and net job reallocation line plots), whereas periods of relatively high employment growth are associated with low rates of excess job reallocation. When period fixed effects are included (column 2) the coefficient on the one and twoyear lagged excess job reallocation variable becomes positive. The effect of the one-year lagged excess job reallocation rate is positive $(0.088)$ and significant at the $5 \%$ level. The two-year lagged excess job reallocation rate is also positive $(0.051)$, but smaller compared with the one-year lagged effect and not significant at the 10\% level. A $10 \%$ increase in LMA excess job reallocation results in a $0.8 \%$ increase in employment next period. 
Table 2: Regression Results

\begin{tabular}{|c|c|c|c|c|c|c|}
\hline Net, $_{\text {}}$ & (1) & (2) & (3) & (4) & (5) & (6) \\
\hline \multirow[t]{2}{*}{$\operatorname{Excess}_{(-1)}$} & -0.057 & 0.088 & 0.042 & & 0.020 & 0.013 \\
\hline & $(0.032)+$ & $(0.035)^{*}$ & $(0.039)$ & & $(0.039)$ & $(0.040)$ \\
\hline \multirow[t]{2}{*}{ Excess $_{(1-2)}$} & -0.009 & 0.051 & -0.004 & & -0.006 & -0.003 \\
\hline & $(0.031)$ & $(0.035)$ & $(0.038)$ & & $(0.038)$ & $(0.038)$ \\
\hline \multirow[t]{2}{*}{$\mathrm{Net}_{(1-1)}$} & & & & -0.169 & -0.166 & -0.177 \\
\hline & & & & $(0.035)^{* *}$ & $(0.036)^{* *}$ & $(0.036)^{* *}$ \\
\hline \multirow[t]{2}{*}{$\mathrm{Net}_{(1-2)}$} & & & & -0.102 & -0.102 & -0.100 \\
\hline & & & & $(0.034)^{* * *}$ & $(0.035)^{* * *}$ & $(0.035)^{* *}$ \\
\hline \multirow[t]{2}{*}{ JC $\%$ Births $_{(1-1)}$} & & & & & & -1.019 \\
\hline & & & & & & $(2.181)$ \\
\hline \multirow[t]{2}{*}{ JC \% Births $_{(t-2)}$} & & & & & & -0.997 \\
\hline & & & & & & $(2.139)$ \\
\hline \multirow[t]{2}{*}{ JC $\%$ Deaths $_{(t-1)}$} & & & & & & 3.924 \\
\hline & & & & & & $(2.046)^{+}$ \\
\hline \multirow[t]{2}{*}{ JD \% Deaths $s_{(1-2)}$} & & & & & & 0.282 \\
\hline & & & & & & $(2.022)$ \\
\hline Period FE & & $\mathrm{Y}$ & $\mathrm{Y}$ & $\mathrm{Y}$ & $\mathrm{Y}$ & $\mathrm{Y}$ \\
\hline LMA FE & & & $\mathrm{Y}$ & $\mathrm{Y}$ & $\mathrm{Y}$ & $\mathrm{Y}$ \\
\hline \multirow[t]{2}{*}{ Constant } & 3.722 & -5.081 & -0.603 & 0.805 & 0.206 & -0.256 \\
\hline & $(1.064)^{* *}$ & $(1.288)^{* *}$ & $(2.087)$ & $(1.084)$ & $(2.061)$ & $(2.575)$ \\
\hline Observations & 770 & 770 & 770 & 770 & 770 & 770 \\
\hline$R$-squared & 0.01 & 0.29 & 0.38 & 0.40 & 0.40 & 0.41 \\
\hline
\end{tabular}

Standard errors in parenthesis, + significant at the at $10 \%$ level, $* 5 \%$ level, ** $1 \%$ level

$\mathrm{N}=55 \mathrm{LMA}^{*} 14$ periods. The first two periods are dropped as they do not have two lagged periods.

When lagged employment growth variables are included the coefficient on the one-year lagged excess job reallocation variable is halved from 0.042 to 0.020 . Controlling for compositional differences in job reallocation between LMAs roughly halves the effect again on lagged excess job reallocation to 0.013 . Across the specifications in columns 2 to 6 the size of the coefficient on the one-year lagged excess job reallocation variable decreases from 0.088 to 0.013 , but the standard errors remain around 0.04 , so the point estimate becomes less statistically significant. The economic significance of the effect of one-year lagged excess job reallocation on net employment growth also diminishes. The estimated one-year lagged excess job reallocation coefficients reported in columns 5 and 6 , of Table 2, suggest that a one standard deviation $(4.7 \%)$ increase in excess job reallocation would raise the mean employment growth rate $(1.8 \%)$ by less than a $10^{\text {th }}$ of a percent.

The coefficients on the compositional variables are negative for the percentage of job creation that is due to firm births and positive for the percentage of job destruction that is due to firm deaths. The effect of composition effects suggest that job creation is primarily within existing firms prior to growth and that job destruction is within firms that die. Only the one-year lagged proportion of job destruction due to firms dieing is significant at the $10 \%$ level.

\section{Conclusion}

The regression results, from Table 1 , do not provide strong evidence to support the hypothesis that excess job reallocation boosts future employment growth within LMAs. Although the regression model did estimate a positive and significant relationship between excess job reallocation and next period employment growth the statistical and economic significance of the estimated coefficient was reduced once other omitted variables were included.

There is some evidence to suggest that an increase in the proportion of job destruction within firms that die results in higher employment growth rates in the next annual period. A possible explanation for the importance of firm deaths, prior to periods of employment growth, is that firm deaths release more (capital and labour) resources into the LMA, compared with layoffs from existing firms. 


\section{Further Work}

This paper aggregated job flows across all industries and provided little evidence of a relationship between the level of excessive job churn and future employment growth within LMAs. However, this does not mean that job flows are not important for employment growth within particular industries. It may also be the case that for certain industries the level of job creation and destruction within the LMA is also beneficial for future growth. Further work could be undertaken to examine the separate effects of job flows within industry groups and LMAs on industry employment growth.

Motu has already begun looking at job flow patterns within industry groups to examine whether the level and mix of job creation and destruction, within an industry group, is related to how geographically concentrated the industry is.

\section{Notes}

1. The work presented in this paper was supported by funding from FoRST, and forms part of Motu's 'Understanding Adjustment and Inequality' research programme. The results presented in this study are the work of the authors and do not necessarily reflect the views of FoRST, or of Statistics New Zealand, whose data were used.

2. For example, see Davis and Haltiwanger (1992).

3. $\Delta \mathrm{e}_{\mathrm{it}}=-2$ corresponds to a firm death - i.e. it loses all of its year-(t-1) employment. Similarly, $\Delta \mathrm{e}_{\mathrm{it}}=2$ corresponds to a firm birth - i.e. it gains all of its year-t employment. For units that have zero employment in each year, we have assigned $\Delta \mathrm{e}_{\mathrm{it}}=-2$ if the unit is removed from the BDS between year-(t1) and $\mathrm{t} ; \Delta \mathrm{e}_{\mathrm{it}}=0$ if it exists in both years; and $\Delta \mathrm{e}_{\mathrm{it}}=2$ if it is 'birthed' between year-( $\mathrm{t}-1)$ and $\mathrm{t}$.

4. This section draws on Carroll et al. (2002) and Statistics New Zealand (2004).

5. The ABFU survey is administered to all businesses except farm type agriculture enterprises, and those that are not part of a group of enterprises and have no paid employees. Prior to 1997 the survey was called the Annual Business Directory Update Survey. The response rate to the ABFU survey is about $90 \%$ overall, but higher for larger firms. In the case of non-response, the Business Frame carries forward the last known survey details. There are approximately 100,000 smaller enterprises, which are not covered by the ABFU. In addition, enterprises that indicate to the IRD that they have no paid employees have their data for working proprietors estimated from the data provided to the IRD. The ABFU collects a variety of information, including number of employees, overseas ownership and activities, location, and main activity.
6. GST is a broad-based sales tax, introduced on 1 October 1986 at the rate of $10 \%$, and increased on 1 July 1989 to $12.5 \%$. The few GST-exempt industries include banking and financial services, superannuation and life insurance and residential property leasing and rental. Businesses must register for GST, and therefore be added to the IRD client registration file, if they are conducting a taxable activity and their annual turnover has exceeded, or is expected to exceed, $\$ 40,000$ (this was increased from $\$ 30,000$ as of 1 October 2000). The Client Registration File currently includes 530,000 enterprises. For GST-exempt financial services enterprises, SNZ supplements the Client Registration File data using various sources, including association lists, financial reports, and a list of superannuation (pension) schemes from the Government Actuary. In addition, in order to ensure appropriate timing of firm births and deaths Statistics New Zealand uses a variety of other sources including its own surveys and media reports to identify businesses for entry onto and exit from the business frame.

7. Statistics New Zealand (2004) defines a geographic unit as "a separate operating unit engaged in New Zealand in one, or predominantly one, kind of economic activity from a single physical location or base"; while it defines an enterprise as "a business operating in New Zealand". Thus an enterprise will consist of one or more geographic units.

8. Newell and Papps (2001) define two sets of labour market areas - one with 140 areas and one with 58 . We have chosen to use the more aggregated areas.

9. Carroll et al. (2002) also used SNZ BDS data. Differences between job reallocation rates, between the two studies, are due to different industry coverages.

10. The countries included by Davis and Haltiwanger were determined by the availability of data and included the U.S., European countries (including the U.K.) and a couple of countries from South America

11. The OECD data is cited by Davis and Haltiwanger (1999) as part of their cross-country survey of firm dynamics.

12. Other work within New Zealand has been conducted by Johnson (1999) - based on an earlier study by Gorringe (1997) - who analysed New Zealand firm dynamics between 1987 and 1999. Johnson and Gorringe measured employment using full-timeequivalents and focused on job creation and destruction due to firm births and deaths.

13. Davis and Haltiwanger (1991) found a similar effect in the U.S. Using 9 regions the percentage of between excess job reallocation was almost zero.

14. $\Delta e_{1}^{\text {gross }}=\Delta e_{1}^{c}+\Delta e_{1}^{d}, \Delta e_{t}^{x s}-\left|\Delta e_{t}^{n e t}\right|$ 


\section{References}

Caballero, R. J. and M. L. Hammour. 1994. "On the timing and efficiency of creative destruction," Working Paper No. 4768, NBER, Cambridge. Available online at www.nber.org.

Carroll, N., D. Hyslop, D Maré, J. Timmins and J. Wood. 2002. "An Analysis of New Zealand's Business Demography Database," New Zealand Economic Papers, 36:1, pp. 59-62.

Cooper, R., J. Haltiwanger and L. Power. 1999. "Machine Replacement and the Business Cycle: Lumps and Bumps," The American Economic Review, 86:4, pp. 921-946.

Davis, S. J. and J. Haltiwanger. 1991. "Gross job creation, gross job destruction and employment reallocation," 3728, NBER, Cambridge. Available online at www.nber.org.

Davis, S. J. and J. Haltiwanger. 1992. "Gross job creation, gross job destruction and employment reallocation," Quarterly Journal of Economics, 107:3, pp. 819-863.

Davis, S. J. and J. Haltiwanger. 1999. "Gross Job Flows," in Handbook of Labour Economics, Vol. 3B. Ashenfelter, O. C. and D. Card (Eds.). Amsterdam: Elsevier, pp. 2711-2807.
Gorringe, P. 1997. "Principal results from analysis of business directory data," Unpublished New Zealand Treasury working paper, New Zealand Treasury, Wellington.

Johnson, B. 1999. "Business dynamics 1987-1999 draft," Unpublished New Zealand working paper, New Zealand Treasury, Wellington.

Mills, D. and J. Timmins. 2004. "Firm Dynamics in New Zealand: A Comparative Analysis with OECD Countries," New Zealand Treasury, Wellington. Available online at www.treasury.govt.nz.

Newell, J. O. and K. L. Papps. 2001. "Identifying Functional Labour Market Areas in New Zealand: A Reconnaissance Study using Travelto-Work Data," Occasional Paper 2001/6, Department of Labour, Wellington. Available online at http: \www.dol.govt.nz.

OECD. 1996. "Job creation and loss: analysis, policy and data development."

Schumpeter, J. A. 1942. Captialism, socialism and democracy, London: Unwin University Books.

Statistics New Zealand. 2004. "Business Demographic Statistics (Analytical Report)," Wellington. Available online at http://www.stats.govt.nz/ analytical-reports/business-demog-stats/ default.htm. 